\title{
A Rare Co-Existing of Hip and Knee Joint's Synovial Chondromatosis: A Case Report
}

\author{
Nadir Görülen Kalça ve Diz Sinoviyal Kondromatozis Birlikteliği: Bir Olgu Sunumu
}

Fatih Bağcıer, Ayhan Kul, Emine Esra Ergül, Akın Erdal

Atatürk University Faculty of Medicine, Department of Physical Medicine and Rehabilitation, Erzurum, Turkey

\section{To the Editor;}

A 29-year-old male patient presented to our clinic with progressively worsening bilateral hip pain, right knee pain and swelling. The hip and knee pain started about 3 months ago and increased over time. Pain of the hip joints was spreading bilaterally to the trochanteric regions. The characteristic of the pain was mechanical. He did not feel pain while sleeping. Prolonged sitting or standing caused the hip to lock. Previously, he had received analgesic medications but there had been no significant improvement. There was no pain in any other joint, and there was no history of disease or trauma associated with the hip and knee. Physical examination revealed an antalgic gait and the patient had visibly swollen right popliteal fossa. The motion of the right hip joint was limited and painful in all directions, whereas lumbar and left hip joint motions were unrestricted. He could fully extend his knee, but flexion was restricted to only 120 degrees. Radiography of the pelvis and knee indicated a narrowing joint space, and there were erosions on the acetabular side of the joint and multiple soft tissue calcifications outside the joint capsule of the right knee. Magnetic resonance imaging (MRI) of the bilateral hip revealed findings consistent with synovial chondromatosis, which filled the joint space completely and MRI of the knee revealed expanded sinovium that contained osteochondromas, which were hypointense in all sequences (Figure 1). Orthopedic surgical procedures including arthroscopic debridement were planned with symptomatic right hip and right knee joints.

Synovial osteochondromatosis is a rare benign condition characterized by the formation of multiple nodules of hyaline cartilage within the sub-synovial connective tissue (1). The condition is generally monoarticular and involves the knee in more than $50 \%$ of the cases (2). The other common joints involved are hip, elbow, shoulder and ankle. In the literature, Kose et al. (3) presented a unilateral hip joint synovial osteochondromatosis case, Mackenzie et al. (4) presented
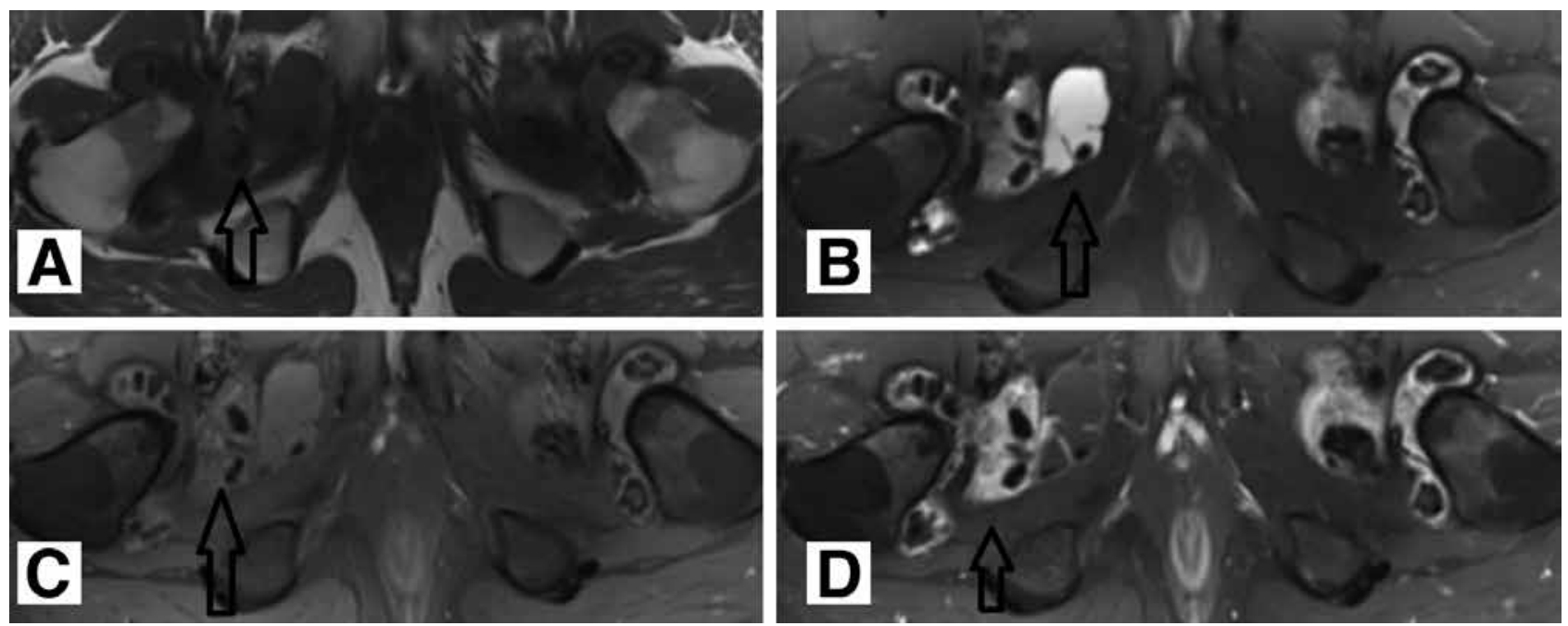

Figure 1. Axial T1 weighted (A), T2 weighted (B), fat saturated T1 weighted (C) and contrast enhanced (D) hip magnetic resonance images of 27 years old man revealed expanded sinovium that contained osteochondromas, which were hypointense all magnetic resonance sequences, magnetic resonance images also revealed sinovial contrast enhancement on contrast enhaced sequence

Address for Correspondence/ Yazışma Adresi: Fatih Bağcıer MD, Atatürk University Faculty of Medicine, Department of Physical Medicine and Rehabilitation, Erzurum, Turkey Phone: +90 5056605754 E-mail: bagcier_42@hotmail.com Received/Geliş Tarihi: 28.09.2015 Accepted/Kabul Tarihi: 19.11.2015

Turkish Journal of Osteoporosis, published by Galenos Publishing. / Türk Osteoporoz Dergisi, Galenos Yayınevi tarafindan basılmıştır. 

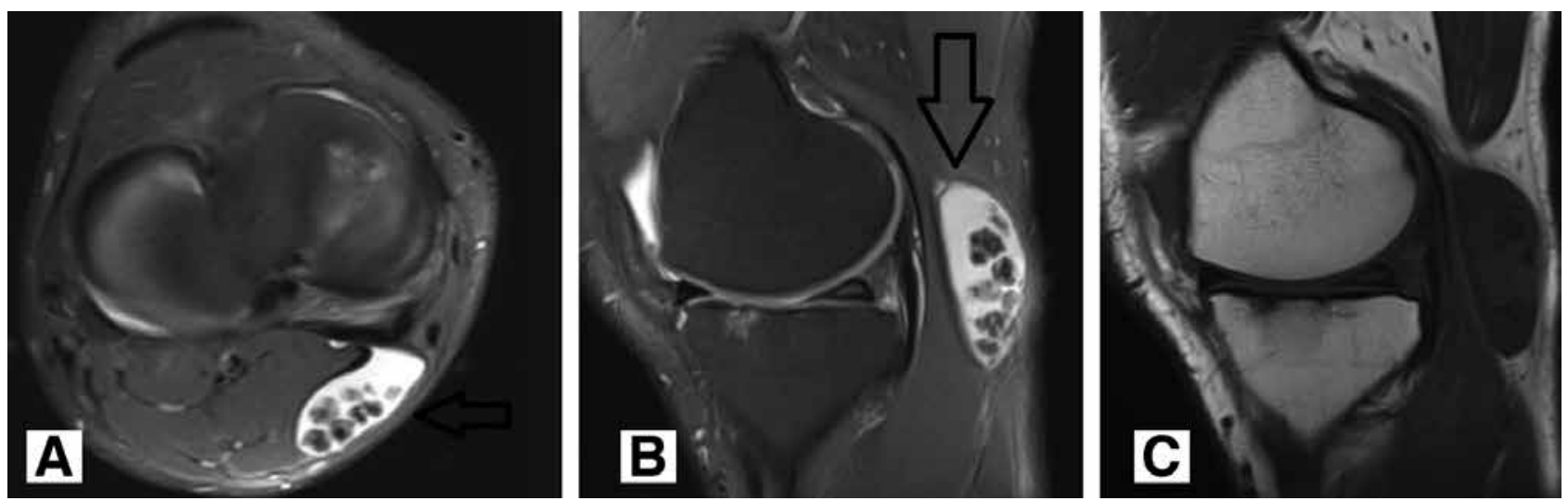

Figure 2. Coronal T2 weighted (A), T1 weighted (B) and and contrast enhanced (C) hip magnetic resonance images of 27 years old man revealed expanded sinovium that contained osteochondromas, which were hypointense all magnetic resonance sequences, magnetic resonance images also revealed sinovial contrast enhancement on contrast enhaced sequence

a unilateral elbow joint synovial osteochondromatosis case, Shearer et al. (5) presented a bilateral ankle joint synovial osteochondromatosis case. In this case, uncommon co-existance of hip and knee involvement was detected. The more common symptoms were chronic, progressive pain, swelling, loss of motion, and locking, and the most common physical signs consisted of soft-tissue swelling, crepitation, palpable loose bodies, and limitated range of motion. As radiotherapy and chemotherapy have no effect on synovial chondromatosis, surgical removal of the affected synovium and the loose bodies is the preferred treatment.

Keywords: Synovial chondromatosis, hip joint, metaplastic disorder

Anahtar kelimeler: Sinoviyal kondromatozis, kalça eklemi, metaplastik değişim

\section{Ethics}

Peer-review: Internal peer-reviewed.

\section{Authorship Contributions}

Surgical and Medical Practices: Fatih Bağcıer, Ayhan Kul, Emine Esra Ergül, Akın Erdal, Concept: Fatih Bağcıer, Ayhan Kul,
Emine Esra Ergül, Akın Erdal, Design: Fatih Bağcıer, Ayhan Kul, Emine Esra Ergül, Akın Erdal, Data Collection or Processing: Fatih Bağcıer, Ayhan Kul, Emine Esra Ergül, Akın Erdal, Analysis or Interpretation: Fatih Bağcıer, Ayhan Kul, Emine Esra Ergül, Akın Erdal, Literature Search: Fatih Bağcıer, Ayhan Kul, Emine Esra Ergül, Akın Erdal, Writing: Fatih Bağcıer.

Conflict of Interest: No conflict of interest was declared by the authors.

Financial Disclosure: The authors declared that this study received no financial support.

\section{References}

1. Sugimoto $K$, Iwai $M$, Kawate $K$, Yajima $H$, Takakura $Y$. Tenosynovial osteochondromatosis of the tarsal tunnel. Skeletal Radiol 2003;32:99-102

2. Walling AK, Gasser SI. Soft-tissue and bone tumours about the foot and ankle. Clin Sports Med 1994;13:909-38.

3. Kose MM, Durmus O, Ayhan MY, Batmaz AG. A rare cause of chronic hip pain: Intraarticular synovial chondromatosis. Acta Reumatol Port 2014;39:349-50.

4. Mackenzie H, Gulati V, Tross S. A rare case of a swollen knee due to disseminated synovial chondromatosis: a case report. J Med Case Rep 2010;4:113.

5. Shearer $H$, Stern P, Brubacher A, Pringle T. A case report of bilateral synovial chondromatosis of the ankle. Chiropr Osteopat 2007;15:18. 